\title{
Vegetation causes channel erosion in a tidal landscape
}

\author{
S. Temmerman \\ University of Antwerpen, Department of Biology, Universiteitsplein 1, 2610 Wilrijk, Belgium \\ T.J. Bouma \\ J. Van de Koppel \\ D. Van der Wal \\ Netherlands Institute of Ecology (NIOO-KNAW), Centre for Estuarine and Marine Ecology, POB 140, 4400 AC Yerseke, Netherlands \\ M.B. De Vries \\ WL I Delft Hydraulics, Rotterdamseweg 185, 2629 HD Delft, Netherlands \\ P.M.J. Herman \\ Netherlands Institute of Ecology (NIOO-KNAW), Centre for Estuarine and Marine Ecology, POB 140, 4400 AC Yerseke, Netherlands
}

\begin{abstract}
Vegetation is traditionally regarded to reduce the erosion of channels in both fluvial and tidal landscapes. We present a coupled hydrodynamic, morphodynamic, and plant growth model that simulates plant colonization and channel formation on an initially bare, flat substrate, and apply this model to a tidal landscape. The simulated landscape evolution is compared with aerial photos. Our results show that reduction of erosion by vegetation is only the local, on-site effect operating within static vegetation. Dynamic vegetation patches, which can expand or shrink, have a contrasting larger scale, off-site effect: they obstruct the flow, leading to flow concentration and channel erosion between laterally expanding vegetation patches. In contrast with traditional insights, our findings imply that in tidal landscapes, which are colonized by denser vegetation, channels are formed with a higher channel drainage density. Hence this study demonstrates that feedbacks between vegetation, flow, and landform have an important control on landscape evolution.
\end{abstract}

Keywords: salt marsh, tidal creek, gully erosion, biogeomorphology.

\section{INTRODUCTION}

Channels serve as the main flow paths for water, sediments, and other materials through many landscapes, and hence play a key role in landscape evolution. Channel formation is traditionally considered to result from feedback between water flow and topography. Flowing water converges in topographic concavities, locally leading to increased shear stress and possibly to erosion of a small initial channel in which the flow and erosion are further concentrated. Models simulate that this flowtopography feedback produces channels in both fluvial (e.g., RodriguezIturbe and Rinaldo, 1997) and tidal landscapes (e.g., D'Alpaos et al., 2005, 2006; Fagherazzi and Furbish, 2001; Marciano et al., 2005).

The channel networks that are observed in tidal marsh landscapes are not scale invariant: small and large channels do not correspond to the same geometric relationships, e.g., between channel width and corresponding basin area (Fagherazzi et al., 1999; Marani et al., 2003; Rinaldo et al., 1999). Scale invariance is, however, a key property of many fluvial channel networks (Rodriguez-Iturbe and Rinaldo, 1997). The absence of scale invariance in tidal channel networks indicates that different channelforming mechanisms act at different scales.

In this paper we hypothesize that plant-flow feedbacks play a crucial role in channel formation, in addition to the classic flow-topography feedback. Tidal marshes may originate from colonization of bare tidal flats by plants, especially Spartina (cordgrass) species. Spartina colonization takes place by initial establishment of individuals, subsequently lateral growth to circular tussocks, which finally coalesce to closed Spartina fields (Callaway and Josselyn, 1992; Hubbard, 1965; Sanchez et al., 2001). We expect that this plant colonization pattern affects flow and erosion-sedimentation patterns. In reverse order, we also expect that flow and erosion-sedimentation patterns determine where plant growth will be successful.

The impact of such feedbacks between plants, water flow, and landform on large-scale landscape evolution is poorly understood (Dietrich and Perron, 2006). Feedbacks between plant growth and erosion- sedimentation were incorporated in models for fluvial landscape evolution (Collins et al., 2004; Istanbulluoglu and Bras, 2005). These models are based on the classic view that vegetation protects the soil from water erosion: the above-ground canopy reduces the erosive forces of flowing water, while below-ground roots strengthen the soil (e.g., Prosser and Slade, 1994; Toy et al., 2002). Hence these models simulate that in fluvial landscapes with a higher vegetation density, channel networks are formed with a lower channel density (Istanbulluoglu and Bras, 2005). The same erosion-reducing effect of vegetation is also assumed for tidal landscapes (e.g., D'Alpaos et al., 2005). In this paper we present field and modeling evidence for a contrasting effect of vegetation: it may initiate concentrated flow and channel erosion, in particular in flat landscapes such as a tidal flat.

\section{METHODS}

Aerial photographs from the Westerschelde estuary (southwest Netherlands) were used to document the patterns of Spartina anglica colonization and channel formation on a tidal flat (Fig. 1). The photos were scanned and georeferenced to the UTM-WGS84 (zone 31) projection. The studied tidal flat is surrounded by subtidal channels. The local mean tidal range is $4.8 \mathrm{~m}$. During a mean high tide, the water depth above the tidal flat is $\sim 0.8 \mathrm{~m}$ (for more details on the study area, see Van Hulzen et al., 2007).

A coupled hydrodynamic, morphodynamic, and plant growth model was used to explain the observed patterns of landscape evolution. The model equations are summarized in GSA Data Repository Tables DR1 and DR2. ${ }^{1}$ The hydrodynamic and morphodynamic models are based on the Delft3D modeling system (e.g., Lesser et al., 2004).

${ }^{1}$ GSA Data Repository item 2007156, Tables DR1 and DR2, modeling plantflow-landform feedbacks, is available online at www.geosociety.org/pubs/ft2007. htm, or on request from editing@geosociety.org or Documents Secretary, GSA, P.O. Box 9140, Boulder, CO 80301, USA. 


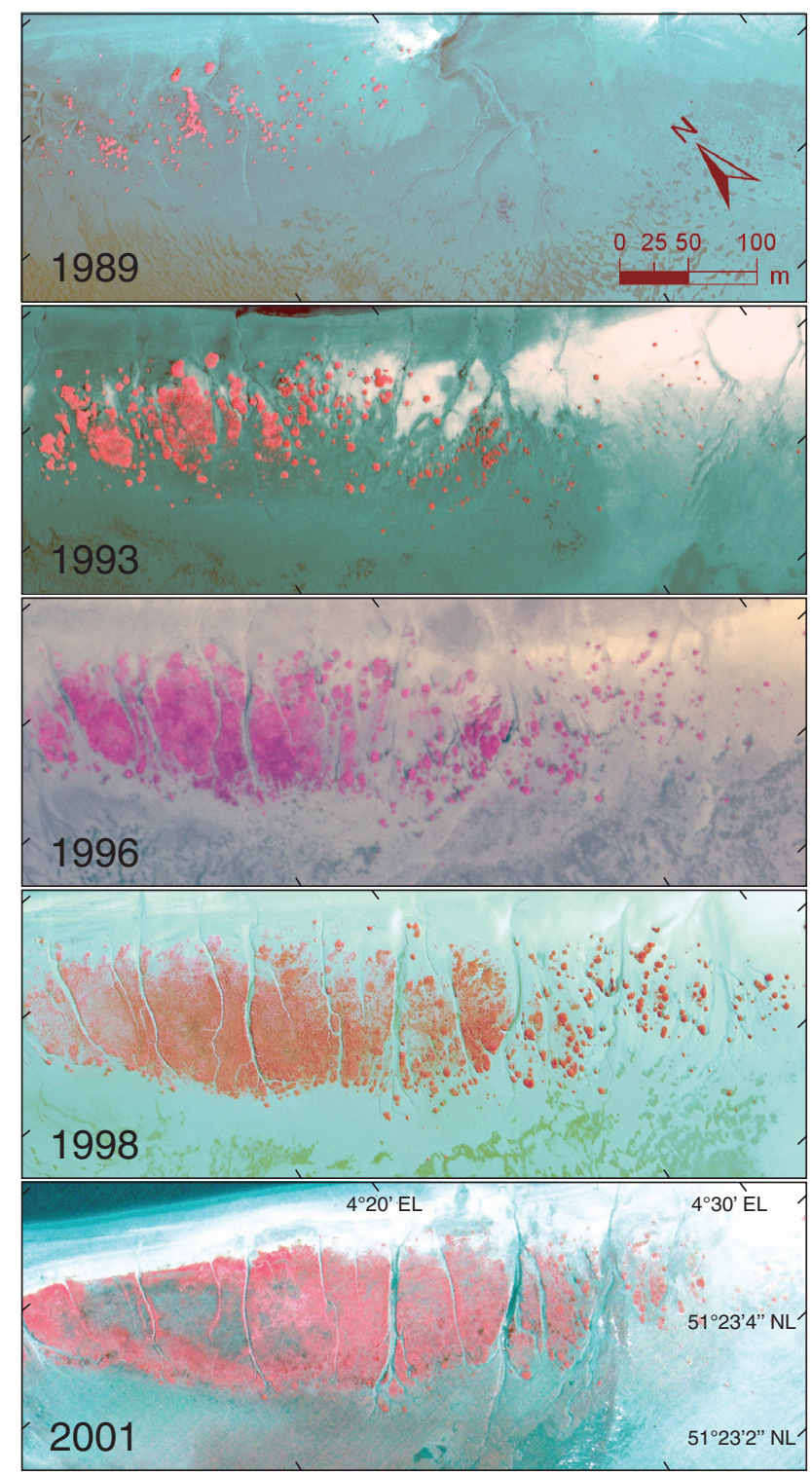

Figure 1. Aerial photographs documenting patterns of plant colonization by Spartina anglica (red color) and channel formation on tidal flat (Plaat van Valkenisse, Scheldt estuary, southwest Netherlands). Tidal flow alternates from top to bottom of photos, and vice versa. All photos are taken at low tide, when area is dry.

The hydrodynamic model computes flow characteristics, such as flow velocities, turbulence generation and dissipation, and bed shear stress, over a three-dimensional finite difference grid, based on the shallowwater equations with a k- $\varepsilon$ turbulence closure model (Lesser et al., 2004). The model explicitly accounts for the influence of rigid cylindrical plant structures (stems, leaves) on drag and turbulence. The plant influence on drag leads in the momentum equations to an extra source term of friction force caused by the plants (equation 1; note that all equations herein are in Table DR1 [see footnote 1]). The plant influence on turbulence leads in the $k-\varepsilon$ equations to an extra source term of turbulent kinetic energy (equations 2-4) and turbulent energy dissipation (equations 5-8) caused by the plants. This plant-flow interaction model has been extensively described and validated against flume data (Bouma et al., 2007) and field measurements on tidal marshes in the study area (Temmerman et al., 2005).

The morphodynamic model is based on the advection-diffusion equation for suspended sediment transport (equation 9). Erosion and sedimentation are modeled as functions of bottom shear stress (equations 10 and 11) and result in net elevation changes (equation 12). This morphodynamic model was also described and validated against field measurements on tidal marshes in the study area (Temmerman et al., 2005).

The plant growth model simulates spatio-temporal changes in stem density of Spartina anglica as the sum of (equation 13): initial plant establishment in bare grid cells of the model grid, which is modeled stochastically (equation 14); lateral expansion of plants to neighboring cells, which is modeled using a diffusion equation (equation 15); growth of stem density within a cell up to its maximum carrying capacity, which is modeled using a logarithmic growth equation (equation 16; commonly used in ecological models [Yodzis, 1989]); plant mortality caused by tidal flow stress, which is modeled as proportional to the bed shear stress exerted by the flow (equation 17); and plant mortality caused by tidal inundation stress, which is modeled as proportional to inundation height at high tide (equation 18).

Input values for the model were obtained from published field data and model calibration (Temmerman et al., 2005, for the hydrodynamic and morphodynamic model; Van Hulzen et al., 2007, for the plant growth model) (Table DR2; see footnote 1). The model was applied to a rectangular grid, representing a horizontal domain of $80 \times 600 \mathrm{~m}$ with a $2 \times 2 \mathrm{~m}$ horizontal resolution and 8 vertical layers (Figs. 2 and 3). Simulations were started from a flat topography (elevation $1.6 \mathrm{~m}$ above mean sea level) without any plants. In each model iteration, the hydrodynamic model is first solved for one average tidal cycle with a time step of $3 \mathrm{~s}$. Tidal action was simulated by imposing a sinusoidal water-level fluctuation at the north and south open boundary of the grid ( amplitude $=2.4 \mathrm{~m}$; period $=745 \mathrm{~min}$; phase difference between both boundaries $=24 \mathrm{~s}$ ). Second, topographic changes were computed with the morphodynamic model and multiplied by the total number of tidal inundations per year to obtain the new topography after a coarse time step of one year. Third, the plant growth model was run to compute the new spatial stem density distribution after the same year. The calculated topography and stem density distribution were used then as input for the next hydrodynamic computation. Feedback loops were run until a stable plant density distribution (average change $<0.1 \mathrm{stems} / \mathrm{m}^{2} / \mathrm{yr}$ ) and stable topography (average elevation change $<0.1 \mathrm{~mm} / \mathrm{yr}$ ) were obtained.

\section{RESULTS}

The first aerial photo (1989) shows an almost bare tidal flat, except from some small vegetation patches, indicating that Spartina colonization just started (Fig. 1A). These patches are all circular, due to lateral clonal expansion of Spartina individuals into tussocks. Some small channels are visible, which were probably formed when plant colonization had not yet started. These channels disappear with ongoing plant colonization on the next photos. By 1993, Spartina tussocks have laterally expanded, resulting in some places in coalescence of neighboring tussocks to larger, irregularly formed vegetation patches (Fig. 1B, left part). Meanwhile the establishment of new small tussocks continues (e.g., central part of photo). No clear channel patterns are visible. By 1996, further establishment, lateral expansion, and coalescence of tussocks resulted in closed Spartina swards (Fig. 1C, left part). These swards are dissected by channels that clearly developed by that time. Establishment and lateral expansion of tussocks continued in the right part of the photo, accompanied by the development of scour holes around and between tussocks. The last two photos (1998 and 2001) show further closing of the vegetation together with channel formation between vegetated areas (Figs. 1D, 1E).

Our model reproduces the observed patterns of plant colonization and channel formation very well (Fig. 2), suggesting that both patterns are the result of plant-flow feedbacks. The simulations start from a completely homogeneous flow field. Once plant establishment starts, simulated flow velocities and bed shear stresses are reduced within and behind vegetation patches, due to friction exerted by the vegetation. In addition, vegetation patches obstruct the flow, resulting in increased flow velocity and bed shear stress between vegetation patches (Fig. 2A). As the lateral expansion of vegetation patches continues, flow becomes increasingly concen- 


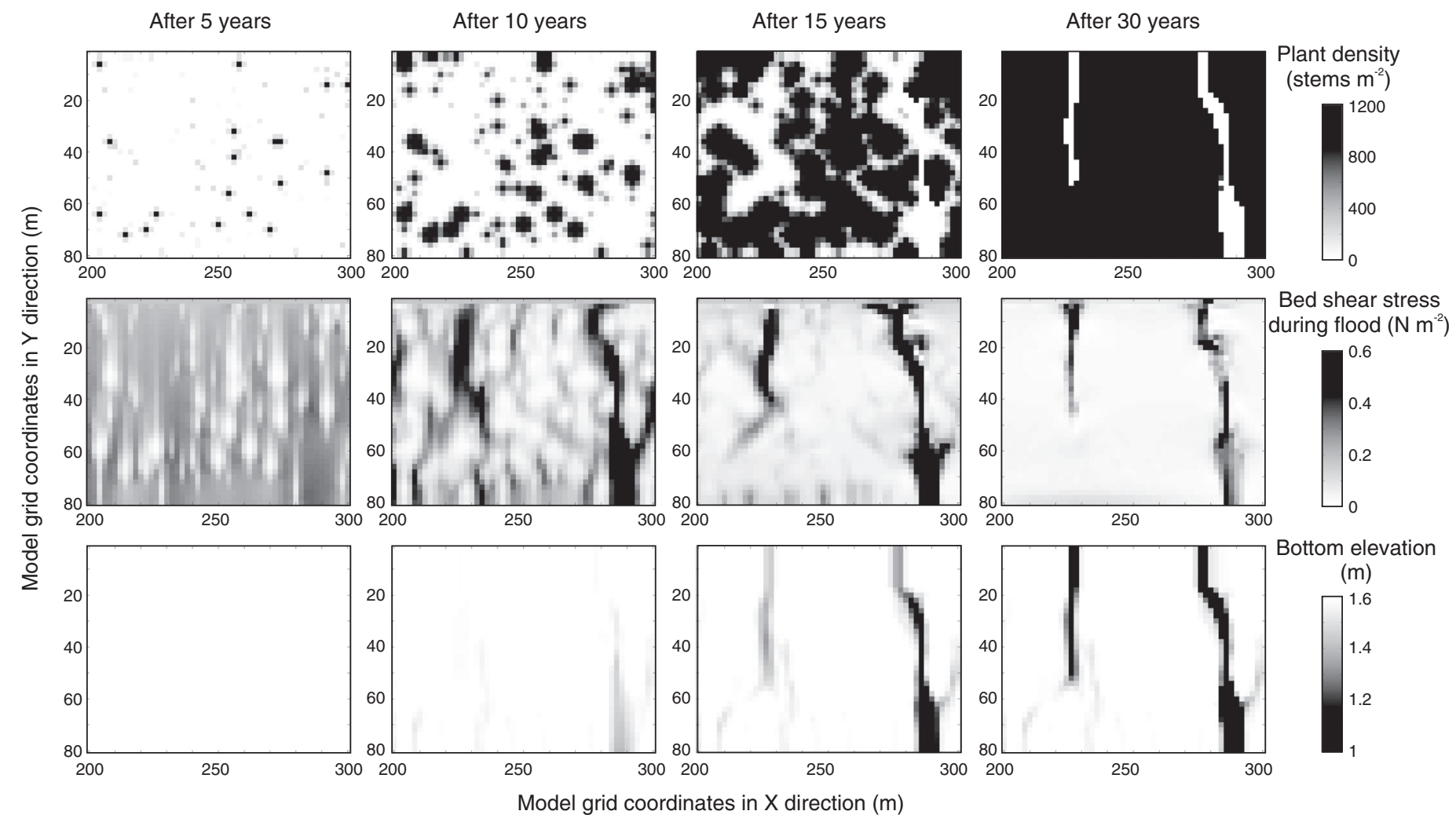

Figure 2. Selected time steps during simulation of plant colonization and channel formation on tidal flat. For each time step, map of plant density (top panels), bed shear stress during peak flood (middle panels), and bottom elevation (bottom panels) are shown for selected part of model grid. Final bottom elevation after $30 \mathrm{yr}$ is shown for complete model grid in Figure $3 \mathrm{~A}$. Flood flow direction is from top to bottom of grid, ebb flow direction is from bottom to top.

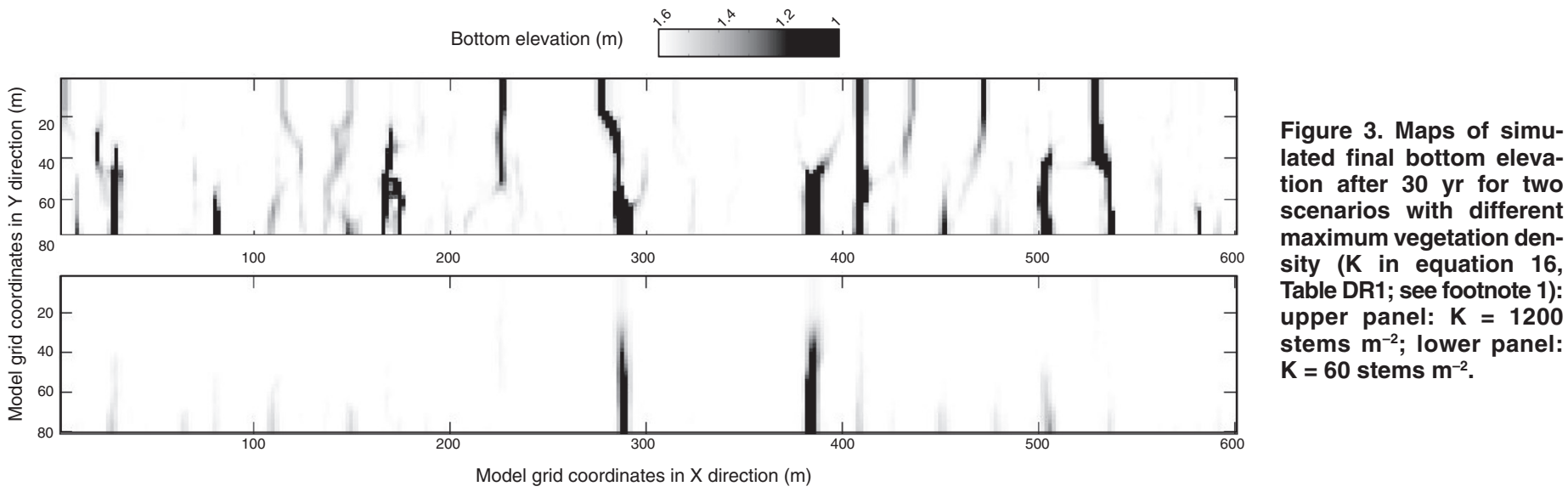

trated between neighboring vegetation patches, leading at a certain moment to bed shear stress levels that are sufficiently high to initiate channel erosion between vegetation patches (Fig. 2B). The increased flow shear stress and water depth in the channels prevent the lateral expansion and growth of vegetation into the channels. Hence the model area finally evolves to a vegetated platform dissected by unvegetated channels (Fig. 2D).

Additional simulations were performed to investigate the effect of increased vegetation density on channel density. These simulations, using vegetations with different maximum stem density ( $\mathrm{K}$ in equation 16 ), indicate that channel density increases with vegetation density (Fig. 3). The higher the vegetation density is within vegetation patches, the stronger the flow concentration is between these vegetation patches, so that a denser pattern of channels is eroded.

\section{DISCUSSION AND CONCLUSIONS}

The present study highlights the role of plant-flow feedbacks in the formation of channels, in particular in a flat landscape such as a tidal marsh. This finding is in strong contrast with the general view that vegetation reduces the erosion of fluvial and tidal channels (e.g., Collins et al., 2004; D'Alpaos et al., 2005; Istanbulluoglu and Bras, 2005; Prosser and Slade, 1994).

Our study showed that reduction of erosion is only a local, on-site effect operating within a static vegetation patch. Dynamic vegetation patches, which may expand or shrink, have a contrasting larger-scale, off-site effect: they obstruct the flow, therefore causing flow concentration and channel erosion between laterally expanding vegetation patches (Figs. 1 and 2). The latter mechanism implies that in landscapes, which are colonized by denser 
vegetation, channels are formed with a higher channel density (Fig. 3). This is in contrast with the findings of fluvial landscape evolution models that only incorporate the traditional, erosion-reducing effect of vegetation and hence simulate lower channel densities in landscapes covered by denser vegetation (Istanbulluoglu and Bras, 2005; Collins et al., 2004).

Our aerial photo observations and model results are in close agreement with early studies on tidal marsh development. In their descriptive botanical studies of European salt marshes, Yapp et al. (1917) and Hubbard (1965) mentioned the formation of tidal channels between laterally expanding, tussock-forming vegetations of Puccinellia maritima and Spartina anglica, respectively: both papers illustrated this with time-series photographs, comparable to our aerial photos (Fig. 1). Recent work showed that local erosion of scour holes may occur around Spartina tussocks (Bouma et al., 2007; Van Hulzen et al., 2007). Colonization of tidal flats by laterally expanding Spartina tussocks is widely reported from other tidal areas throughout the world (e.g., Callaway and Josselyn, 1992; Sanchez et al., 2001). This suggests that the role of plant-flow feedbacks in tidal channel formation is not restricted to our study area, but probably widespread.

The formation of channels by plant-flow feedbacks may explain why the geometric properties of channel networks in tidal marshes are not scale invariant: analyses showed that large and small tidal marsh channels do not correspond to the same geometric relationships between, e.g., channel width and basin area (Fagherazzi et al., 1999; Marani et al., 2003; Rinaldo et al., 1999). These authors interpreted the absence of scale invariance as the result of different channel-forming mechanisms, acting on different scales. Flow-topography feedback is one widely accepted mechanism for tidal channel formation (e.g., D'Alpaos et al., 2005, 2006; Fagherazzi and Furbish, 2001; Marciano et al., 2005). By showing that plant-flow feedbacks also play a crucial role in tidal channel erosion, our study is, to our knowledge, the first that hints at the direction where we may find alternative channel-forming mechanisms.

Our findings may have important implications for the evolution of other landscapes than tidal landscapes. We may expect that plant-flow feedbacks are most important in landscapes, where topographic gradients and soil conditions are rather homogeneous in space. For example, channel formation in alluvial river floodplains is likely to interact with colonization patterns of aquatic and riparian vegetation (Gran and Paola, 2001; Murray and Paola, 2003; Coulthard, 2005). On hill slopes, runoff water may flow around vegetation patches, which may concentrate flow and initiate channel erosion (Emmet, 1978; Bochet et al., 2000). This raises the intriguing question to what extent the large-scale formation and evolution of many landscapes are controlled by feedbacks between vegetation, flow, and landform (Dietrich and Perron, 2006). Our modeling study offers interesting perspectives to further explore this question.

\section{ACKNOWLEDGMENTS}

This work was funded by a European Union Marie Curie Fellowship to Temmerman. We thank Rijkswaterstaat for providing the aerial photos and WL I Delft Hydraulics for providing and assisting with the Delft3D model. This is NIOO-KNAW publication number 4011.

\section{REFERENCES CITED}

Bochet, E., Poesen, J., and Rubio, J.L., 2000, Mound development as an interaction of individual plants with soil, water erosion and sedimentation processes on slopes: Earth Surface Processes and Landforms, v. 25, p. 847-867, doi: 10.1002/1096-9837(200008)25:8<847:AID-ESP103>3.0.CO;2-Q.

Bouma, T.J., Van Duren, L.A., Temmerman, S., Claverie, T., Blanco-Garcia, A., Ysebaert, T., and Herman, P.M.J., 2007, Spatial flow and sedimentation patterns within patches of epibenthic structures: Continental Shelf Research (in press), doi: 10.1016/j.csr.2005.12.019.

Callaway, J.C., and Josselyn, M.N., 1992, The introduction and spread of smooth cordgrass (Spartina alterniflora) in South San Francisco Bay: Estuaries, v. 15 , p. 218-226, doi: $10.2307 / 1352695$.

Collins, D.B.G., Bras, R.L., and Tucker, G.E., 2004, Modeling the effects of vegetation-erosion coupling on landscape evolution: Journal of Geophysical Research, v. 109, F03004, doi: 10.1029/2003JF000028.
Coulthard, T.J., 2005, Effects of vegetation on braided stream pattern and dynamics: Water Resources Research, v. 41, W04003, doi: 10.1029/2004WR003201.

D’Alpaos, A., Lanzoni, S., Marani, M., Fagherazzi, S., and Rinaldo, A., 2005, Tidal network ontogeny: Channel initiation and early development: Journal of Geophysical Research, v. 110, F02001, doi: 10.1029/2004JF000182.

D’Alpaos, A., Lanzoni, S., Mudd, S.M., and Fagherazzi, S., 2006, Modeling the influence of hydroperiod and vegetation on the cross-sectional formation of tidal channels: Estuarine, Coastal and Shelf Science, v. 69, p. 311-324, doi: 10.1016/j.ecss.2006.05.002.

Dietrich, W.E., and Perron, J.T., 2006, The search for a topographic signature of life: Nature, v. 439, p. 411-418, doi: 10.1038/nature04452.

Emmet, W.W., 1978, Overland flow: Chichester, UK, Wiley, p. 145-176.

Fagherazzi, S., and Furbish, D.J., 2001, On the shape and widening of salt marsh creeks: Journal of Geophysical Research, v. 106, p. 991-1003, doi: 10.1029/1999JC000115.

Fagherazzi, S., Bortoluzzi, A., Dietrich, W.E., Adami, A., Lanzoni, S., Marani, M., and Rinaldo, A., 1999, Tidal networks 1. Automatic network extraction and preliminary scaling features from digital terrain maps: Water Resources Research, v. 35, p. 3891-3904, doi: 10.1029/1999WR900236.

Gran, K., and Paola, C., 2001, Riparian vegetation controls on braided stream dynamics: Water Resources Research, v. 37, p. 3275-3283.

Hubbard, J.C.E., 1965, Spartina marshes in southern England. VI. Pattern of invasion in Poole Harbour: Journal of Ecology, v. 53, p. 799-813, doi: $10.2307 / 2257637$.

Istanbulluoglu, E., and Bras, R.L., 2005, Vegetation-modulated landscape evolution: Effects of vegetation on landscape processes, drainage density, and topography: Journal of Geophysical Research, v. 110, F02012, doi: 10.1029/2004JF000249.

Lesser, G.R., Roelvink, J.A., Van Kester, J.A.T.M., and Stelling, G.S., 2004, Development and validation of a three-dimensional morphological model: Coastal Engineering, v. 51, p. 883-915, doi: 10.1016/j.coastaleng. 2004.07.014.

Marani, M., Belluco, E., D’Alpaos, A., Defina, A., Lanzoni, S., and Rinaldo, A., 2003, On the drainage density of tidal networks: Water Resources Research, v. 29, article 1040.

Marciano, R., Wang, Z.B., Hibma, A., De Vriend, H.J., and Defina, A., 2005, Modeling of channel patterns in short tidal basins: Journal of Geophysical Research, v. 110, F01001, doi: 10.1029/2003JF000092.

Murray, A.B., and Paola, C., 2003, Modelling the effect of vegetation on channel pattern in bedload rivers: Earth Surface Processes and Landforms, v. 28, p. $131-143$

Prosser, I.P., and Slade, C.J., 1994, Gully formation and the role of valley-floor vegetation, southeastern Australia: Geology, v. 22, p. 1127-1130, doi 10.1130/0091-7613(1994)022<1127:GFATRO>2.3.CO;2

Rinaldo, A., Fagherazzi, S., Lanzoni, S., Marani, M., and Dietrich, E., 1999 Tidal networks 2. Watershed delineation and comparative network morphology: Water Resources Research, v. 35, p. 3905-3917, doi: 10.1029/1999WR900237.

Rodriguez-Iturbe, I., and Rinaldo, A., 1997, Fractal river basins: Chance and selforganization: New York, Cambridge University Press, 564 p.

Sanchez, J.M., SanLeon, D.G., and Izco, J., 2001, Primary colonisation of mudflat estuaries by Spartina maritima (Curtis) Fernald in northwest Spain: Vegetation structure and sediment accretion: Aquatic Botany, v. 69, p. 15-25, doi: 10.1016/S0304-3770(00)00139-X.

Temmerman, S., Bouma, T.J., Govers, G., Wang, Z.B., De Vries, M.B., and Herman, P.M.J., 2005, Impact of vegetation on flow routing and sedimentation patterns: Three-dimensional modeling for a tidal marsh: Journal of Geophysical Research, v. 110, F04019, doi: 10.1029/2005JF000301.

Toy, T.J., Foster, G.R., and Renard, K.G., 2002, Soil erosion: Processes, prediction, measurement, and control: New York, Wiley, 352 p.

Van Hulzen, J.B., Van Soelen, J., and Bouma, T.J., 2007, Morphological variation and habitat modification are strongly correlated for the autogenic ecosystem engineer Spartina anglica (common cordgrass): Estuaries and Coasts, v. 30, p. $1-19$.

Yapp, R.H., Johns, D., and Jones, O.T., 1917, The salt marshes of the Dovey estuary. Part II. The salt marshes: Journal of Ecology, v. 5, p. 65-103, doi: $10.2307 / 2255644$.

Yodzis, P., 1989, Introduction to theoretical ecology: New York, Harper \& Row, $384 \mathrm{p}$.

Manuscript received 31 October 2006

Revised manuscript received 27 February 2007

Manuscript accepted 2 March 2007

Printed in USA 